\title{
BACTERIOSCOPIC METHOD OF THE SNAILS' MEAT FRESHNESS DETERMINATION
}

\author{
I. V. ZABARNA, PhD, Assistent professor \\ of Department of Infectious and Invasive Diseases \\ https://orcid.org/0000-0001-9341-4533 \\ State Agrarian and Engineering University in Podilia, Kamyanets-Podilskyi \\ E-mail: inna-chornenka@ukr.net
}

\begin{abstract}
The aim of the study was to improve and determine the degree of freshness of meat of snails of Helix genus after different technological processing by bacterioscopic method. Since there is no data in the modern scientific literature about the determination of indicators of safety and quality of meat of snails, in particular the freshness of meat of different species and different technological processes by bacterioscopic method, therefore the problem is relevant. The meat of snails of genus Helix has been used for the study, subspecies: Helix pomatia, Helix aspersa maxima and Helix aspersa muller. 30 samples of meat of snails of each species, bred in a snail farm of the Kyiv region were selected for the study. The research was conducted in the winter, when the snails were in anabiosis condition. The meat of snails was investigated after various technological processing: live, chilled and cooked and frozen. According to the results of the study, it was found that the meat of live snails was fresh for 2 days; doubtful freshness - from 3 days to 5 days; stale - in 7 days; freshly chilled meat of snails was fresh in 2 days including; doubtful freshness - from 3 to 6 days; stale - in 7 and 8 days; and coocked and chilled snails' meat was fresh after the storage for 6 months at a temperature of minus $18{ }^{\circ} \mathrm{C}$. These data are stable and reliable, therefore, these indicators can be used in assessing the safety of snail meat under different processing conditions and after different storage periods.
\end{abstract}

Keywords: microorganisms, Helix pomatia, Helix aspersa maxima, Helix aspersa muller, snails' meat, bacterioscopic performance

\section{Introduction}

Heliciculture, as one of the sources of raw materials for the food industry, has recently attracted more and more specialists. Nowadays, the main consumers of snails are citizens of such countries as France, Italy, Spain, Belgium, Switzerland, Germany, and USA. Meat of the Helix snails has a high nutritional value. The fillets of snails con- tain: $12-18 \%$ of protein; $1,5 \%$ of fats, which contain very useful phospholipids (up to $50 \%$ ); $1,1-1,4 \%$ of carbohydrates; $1,7-2,1 \%$ of mineral salts (Burlaka et al., 2004; Gural-Sverlova and Gural, 2012; Leonov, 2005; Shevchuk et al., 2017).

However, snails' meat is a complex biologically active raw material, in which, under the influence of the environmental and technological factors, processes of 
different nature occur. As a result, this meat easily changes its structure, composition, characteristics and may lose not only qualitative properties, but also be a factor of various infections and diseases. It should be noted that meat is a necessary and valuable component in the human diet, but only if it meets the requirements of safety and quality (Donchenko, 2001; Yakubchak et al., 2017).

Having analyzed the literature on the determination of quality and safety indicators, in particular, the freshness of snails' meat, the lack of normative documentation was revealed. In this regard, the main task is to improve the methods of determining the quality and safety of meat of food snails, to develop new scientifically based veterinary and sanitary rules, standards, technical regulations and instructions. This will contribute to the successful resolution of critical problems not only on safety, but also product quality of snails; in addition, most of existing snail farms will have an opportunity to export their products to the EU (Regulation (EU) 852/2004; Regulation (EU) 853/2004; Yakubchak, 2018; Codex Alimentarius, 1993).

Different microorganisms may be on the surface of the snails' meat taking into account the fact that snails live in the environment and are in a direct contact with soil. By the number of them one can estimate the freshness of meat.

Therefore, providing of a hygienic norms and the use of Good Manufacturing Practices (GMP) should limit microbial infections to the lowest possible level and prevent further spread of infections within the levels of threat. This is why it is necessary to introduce a process control system based on the HACCP procedures to prevent the emergence of hazards associated with meat freshness (Recommended International Code, 1993).
Taking into account the fact that in the modern scientific literature there are no data concerning the determination of freshness of meat of snails of different species and after different technological processes by the bacterioscopic method, the problem is relevant.

The aim of the study is to improve and determine the degree of freshness of Helix snail meat after different technological processing by bacterioscopic method.

\section{Materials and methods of research}

A meat of Helix snails, sub-species: Helix pomatia, Helix aspersa maxima and Helix aspersa muller, were used for the study 30 samples of meat of snails of each species, grown in a snail farm of the Kyiv region were selected for the study. The research was conducted in the winter, when the snails were in anabiosis condition. The meat of snails was investigated under various technological processing: live, chilled and cooked and frozen. Grape snail (Helix pomatia) was studied only in a cooked and frozen state with a shelf life up to 6 months at a temperature of $18^{\circ} \mathrm{C}$, as grape snails enter into hibernation at temperatures below $10{ }^{\circ} \mathrm{C}$; however, at a temperature of $12{ }^{\circ} \mathrm{C}$ they become flabby and not active; at temperature of $10{ }^{\circ} \mathrm{C}$ they stop growing (Burlaka et al., 2004; Popov, 1996; Daguzan,1989). The grape snail is more adapted to the natural climate conditions in the vineyards unlike the Helix aspersa snails species, as well as to the faint green gardens, where Helix asper$s a$ snails in the winter period can actively exist in artificially created conditions.

The method for the results of which it is possible to obtain quantitative indices 
in determining the amount of bacteria and the breakdown of muscle tissue by bacterioscopy of smears of fingerprints from snail meat was improved. The research was carried out using crushed muscle tissue of snails in the size of $0,5 \times 1,0 \times 1,2 \mathrm{~cm}$, which, by different sides, was applied to 2 objective specimens, making 3 smears on each, then dried in the air, fixed three times over a flame of alcohol lamp, and used chemical dishes with appropriate reagents, consistently stained received preparations by Gram staining. Preparations with three smears were microscopied using a light microscope with $90^{x}$ zoom lens and $15^{x}$ eyepiece using immersion oil. On the two objective glasses in 3 smears 25 fields of view were examined, counting microorganisms, which were stained as gram-positive (violet) and gram-negative (red), displaying an arithmetic mean in 1 field of view after (Patent application for a utility model № u 2019 00992).

The reliability of the difference between the arithmetic meanings of the two variation series was determined according to the Student's criterion, taking into account the validity limit: $p \leq$ 0,$05 ; p \leq 0,01, p \leq 0,001$. The obtained research results were processed using the Microsoft Excel computer program.

\section{Results of the research and their discussion}

The results of the study of meat of snails of different species under different technological processing show that in the meat of live $H$. aspersa mullerr snails in 1-2 days of their withdrawal from anabiosis, a number of microorganisms was by $42,8 \%$ higher than in the meat of the living $H$. aspersa maxima snails. As the snails were investigated alive, so one could observe mucus in large amounts, it stands out by special snail glands in response to physical stress or damage of the shell. Based on the results of the study, it has been found that the meat of live snails has a fresh degree of freshness in 1-2 days of their withdrawal from anabiosis (Table 1).

According to the results of the study, it was found that in the meat of live $H$. aspersa mullerr snails in 3 days of their withdrawal from anabiosis, the amount of microorganisms exceeded by $7,2 \%$, compared with the meat of live $H$. aspersa maxima snails; different forms of cocci gram-positive microorganisms dominated in most fields of view, and mucus in a significant amount was observed. At the same time, the results of the study of the meat of live $H$. aspersa mullerr snails in 5 days of their withdrawal from anabiosis show, that the number of microorganisms was higher by $54,6 \%(p \leq 0,01)$, compared to the meat of live $H$. aspersa maxima snails, mucus was in large amounts, in most fields of view cocci gram-positive microorganisms were prevailing. According to the results of the study, it was found that the meat of live snails (H. aspersa mullerr, H. aspersa maxima) in 3-5 days of their withdrawal from anabiosis was of a doubtful degree of freshness.

In the meat of live $H$. aspersa mullerr snails in 7 days of their withdrawal from anabiosis, the number of microorganisms was by $3,2 \%$ higher, in comparison with the meat of live $H$. aspersa maxima snails; they observed cocci and coli forms of microorganisms, gram-positive, the traces of the breakdown of muscle tissue was observed. The data obtained show that the meat of live snails ( $H$. aspersa mullerr, H. aspersa maxima) in 7 days of their withdrawal from the anabiosis is stale.

In addition, we have studied the chilled meat of snails after 2 days of storage at a temperature of $\left(2-6{ }^{\circ} \mathrm{C}\right)$. The results of the study indicate that the number of microorganisms in the chilled 


\section{Indicators of the degree of freshness of snails' meat using bacterioscopic method, $M \pm \mathbf{m}, \mathbf{n}=\mathbf{3 0}$}

\begin{tabular}{|c|c|c|c|c|}
\hline \multirow{2}{*}{$\begin{array}{l}\text { Technological process- } \\
\text { ing of snails meat and } \\
\text { storage time }\end{array}$} & \multirow[t]{2}{*}{ Snails species } & \multicolumn{3}{|c|}{$\begin{array}{l}\text { Degrees of freshness of snails meat, } \\
\text { the number of microorganisms }\end{array}$} \\
\hline & & Fresh meat & Doubtful freshness & Stale meat \\
\hline \multirow{2}{*}{$\begin{array}{l}\text { The meat of living } \\
\text { snails in } 1-2 \text { days after } \\
\text { their withdrawal from } \\
\text { anabiosis }\end{array}$} & H. aspersa maxima & $\begin{array}{c}4,20 \pm 0,512 \\
\text { mucus in large } \\
\text { amounts }\end{array}$ & \multirow{2}{*}{-} & \multirow{2}{*}{-} \\
\hline & H. aspersa mullerr & $\begin{array}{l}6,0 \pm 0,422 \\
\text { mucus in a signifi- } \\
\text { cant amount }\end{array}$ & & \\
\hline \multirow{2}{*}{$\begin{array}{l}\text { The meat of living } \\
\text { snails in } 3 \text { days after } \\
\text { their withdrawal from } \\
\text { anabiosis }\end{array}$} & H. aspersa maxima & \multirow{2}{*}{-} & $\begin{array}{l}11,0 \pm 0,365 \\
\text { mucus in a signifi- } \\
\text { cant amount, Gr+ } \\
\text { cocci }\end{array}$ & \multirow{2}{*}{-} \\
\hline & H. aspersa mullerr & & $\begin{array}{c}11,8 \pm 0,467 \\
\text { mucus in a signifi- } \\
\text { cant amount, Gr+ } \\
\text { cocci }\end{array}$ & \\
\hline \multirow{2}{*}{$\begin{array}{l}\text { The meat of living } \\
\text { snails in } 5 \text { days after } \\
\text { their withdrawal from } \\
\text { anabiosis }\end{array}$} & H. aspersa maxima & \multirow[b]{2}{*}{-} & $\begin{array}{c}13,0 \pm 0,615 \\
\text { mucus in a signifi- } \\
\text { cant amount, Gr+ } \\
\text { cocci }\end{array}$ & \multirow[b]{2}{*}{-} \\
\hline & H. aspersa mullerr & & $\begin{array}{c}20,1 \pm 0,781^{*} \\
\text { mucus in a signifi- } \\
\text { cant amount, Gr+ } \\
\text { cocci }\end{array}$ & \\
\hline \multirow{2}{*}{$\begin{array}{l}\text { The meat of living } \\
\text { snails in } 7 \text { days after } \\
\text { their withdrawal from } \\
\text { anabiosis }\end{array}$} & H. aspersa maxima & \multirow{2}{*}{-} & \multirow{2}{*}{-} & $\begin{array}{c}43,6 \pm 0,686 \\
\text { traces of muscle } \\
\text { tissue breakdown, } \\
\text { Gr+ cocci and coli }\end{array}$ \\
\hline & H. aspersa mullerr & & & $\begin{array}{c}45,0 \pm 0,516 \\
\text { traces of muscle } \\
\text { tissue breakdown, } \\
\text { Gr+ cocci and coli }\end{array}$ \\
\hline \multirow{2}{*}{$\begin{array}{l}\text { Chilled snails meat in } \\
2 \text { days of storage at the } \\
\text { temperature of } \\
\left(2-6^{\circ} \mathrm{C}\right)\end{array}$} & H. aspersa maxima & $\begin{array}{c}5,80 \pm 0,467 \\
\text { small amounts of } \\
\text { mucus }\end{array}$ & \multirow{2}{*}{-} & \multirow[t]{2}{*}{ 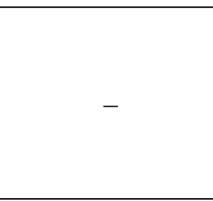 } \\
\hline & H. aspersa mullerr & $\begin{array}{c}11,0 \pm 0,471^{* *} \\
\text { small amounts of } \\
\text { mucus }\end{array}$ & & \\
\hline \multirow{2}{*}{$\begin{array}{l}\text { Chilled snails meat in } \\
4 \text { days of storage at the } \\
\text { temperature of } \\
\left(2-6^{\circ} \mathrm{C}\right)\end{array}$} & H. aspersa maxima & \multirow[t]{2}{*}{ (1) } & $\begin{array}{c}15,0 \pm 0,577 \\
\text { traces of mucus are } \\
\text { not observed }\end{array}$ & \multirow{2}{*}{-} \\
\hline & H. aspersa mullerr & & $\begin{array}{c}16,8 \pm 0,611 \\
\text { traces of mucus are } \\
\text { not observed }\end{array}$ & \\
\hline \multirow{2}{*}{$\begin{array}{l}\text { Chilled snails meat in } \\
6 \text { days of storage at the } \\
\text { temperature of } \\
\left(2-6^{\circ} \mathrm{C}\right)\end{array}$} & H. aspersa maxima & \multirow[b]{2}{*}{-} & $\begin{array}{c}25,7 \pm 1,136 \\
\text { traces of mucus are } \\
\text { not observed, Gr+ } \\
\text { cocci }\end{array}$ & \multirow[b]{2}{*}{-} \\
\hline & H. aspersa mullerr & & $\begin{array}{c}22,4 \pm 0,686 \\
\text { traces of mucus are } \\
\text { not observed, Gr+ } \\
\text { cocci }\end{array}$ & \\
\hline
\end{tabular}




\begin{tabular}{|c|c|c|c|c|}
\hline \multirow{2}{*}{$\begin{array}{l}\text { Chilled snails meat in } \\
8 \text { days of storage at the } \\
\text { temperature of } \\
\left(2-6^{\circ} \mathrm{C}\right)\end{array}$} & H. aspersa maxima & \multirow{2}{*}{-} & \multirow{2}{*}{-} & $\begin{array}{c}85,5 \pm 0,500 \\
\text { traces of muscle } \\
\text { tissue breakdown, } \\
\text { Gr+ bacteria }\end{array}$ \\
\hline & H. aspersa mullerr & & & $\begin{array}{c}65,0 \pm 0,471^{* * *} \\
\text { traces of muscle } \\
\text { tissue breakdown, } \\
\text { Gr+ bacteria }\end{array}$ \\
\hline \multirow{3}{*}{$\begin{array}{l}\text { Coocked and frozen } \\
\text { snails meat after storage } \\
\text { for } 6 \text { months at a tem- } \\
\text { perature of minus } 18^{\circ} \mathrm{C}\end{array}$} & H. aspersa maxima & $\begin{array}{l}6,9 \pm 0,380 * * * * \\
\text { no mucus }\end{array}$ & \multirow{3}{*}{-} & \multirow{3}{*}{-} \\
\hline & H. aspersa mullerr & $\begin{array}{c}7,9 \pm 0,530 \\
\text { no mucus }\end{array}$ & & \\
\hline & H. pomatia & $\begin{array}{c}9,0 \pm 0,470 \\
\text { no mucus }\end{array}$ & & \\
\hline
\end{tabular}

Note: ${ }^{\star} \mathrm{P}<0,01$ - compared to a meat of $H$. aspersa maxima living snails in 5 days after their withdrawal from anabiosis;

${ }^{*} \mathrm{P}<0,01$ - compared to a meat of $H$. aspersa maxima living snails in 2 days after their withdrawal from anabiosis;

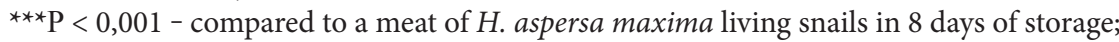

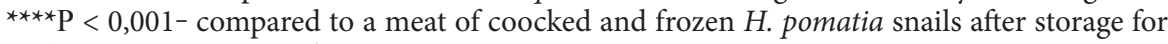
6 months at a temperature of minus $18^{\circ} \mathrm{C}$.

meat of $H$. aspersa mullerr snails was by $89,6 \%(p \leq 0,01)$ higher, compared with the meat of chilled $H$. aspersa maxima snails; mucus in a significant amount was observed, apparently this is due to the technological processing of meat. According to the results of the study, it was found that meat of chilled snails after 2 days of storage at the temperature of $\left(2-6^{\circ} \mathrm{C}\right)$, is considered to be fresh.

The number of microorganisms in the chilled meat of $H$. aspersa mullerr snails after 4 days of storage at a temperature of $\left(2-6{ }^{\circ} \mathrm{C}\right.$ ) was higher by $12,0 \%$ than the number of microorganisms in the meat of chilled $H$. aspersa maxima snails; while in the chilled meat of $H$. aspersa mullerr snails after 6 days of storage at a temperature of $\left(2-6{ }^{\circ} \mathrm{C}\right)$, the number of microorganisms was by $12,8 \%$ lower, compared to the meat of chilled $H$. aspersa maxima snails. In the chilled meat of snails after $4-6$ days of storage, they didn't observe mucus, and in most fields of view cocci gram-positive microorganisms were observed. According to the results of the study, it has been found that chilled meat of snails after $4-6$ days of storage at a temperature of $\left(2-6^{\circ} \mathrm{C}\right)$ is considered to be of a doubtful degree of freshness.

Results of the study on the chilled meat of $H$. aspersa mullerr snails after 8 days of storage at a temperature of $\left(2-6{ }^{\circ} \mathrm{C}\right)$ show that the number of microorganisms was by $23,9 \%(p \leq 0,001)$ higher than in the meat of chilled $H$. aspersa maxima snails. The traces of the breakdown of muscle tissue were found, gram-positive bacteria were dominating. It has been found that chilled meat of snails (H. aspersa mullerr, $H$. aspersa maxima) after 8 days of stor- 
age at a temperature of $\left(2-6^{\circ} \mathrm{C}\right)$ is considered to be the stale one.

However, the study of chilled and cooked meat of $H$. pomatia snails with 6 months of storage terms at a temperature of minus $18{ }^{\circ} \mathrm{C}$ indicates that the number of microorganisms was $9,0 \pm 0,470$, which is by $12,2 \%(p \leq 0,001)$ higher, compared to the indicators of chilled and cooked meat of $H$. aspersa maxima snails; and by $23,3 \%$ higher, compared to the chilled and cooked meat of $H$. aspersa mullerr snails. In addition, a study showed no residual mucus, due to the technological processing of the meat. It has been found, that chilled and cooked meat of snails with 6 months of storage terms at a temperature of minus 18 ${ }^{\circ} \mathrm{C}$ is considered to be a fresh one.

\section{Conclusions and future perspectives}

The conducted researches found that the meat of live snails was fresh for 2 days including; of a doubtful freshness - from 3 days to 5 days including; stale - for 7 days; freshly chilled meat of snails was fresh for 2 days including; of a doubtful freshness from 3 days to 6 days including; stale - in 7 and 8 days; and freshly chilled and cooked meat of snails was fresh after its storage for 6 months at a temperature of minus $18^{\circ} \mathrm{C}$. According to results of the improved bacterioscopic method, quantitative indices were obtained in determining the amount of bacteria and the breakdown of muscle tissue by bacterioscopy of smears of snails' meat of different species and after different processing. These data are stable and reliable, therefore, these indicators can be used in assessing the safety of snail meat after different processing and of different storage periods; they can be also used to determine the degree of freshness of meat of snails by bacterioscopic method in determining their safety in the production laboratories, processing, sale and storage of snail meat, in state laboratories of veterinary medicine.

The prospect of our further research is to study the indicators of the safety and quality of meat of Helix snails after different technological processing, especially conserning biochemical indicators of snails' meat.

\section{References}

Burlaka, V. A., Shevchuk, V. F., Beliaiev, S. M. (2004). Vyroshchuvannia slymaka rodu Helix pomatia v umovakh Polissia Ukrainy. Ekoloho-funktsionalni ta faunistychni aspekty doslidzhen moliuskiv, yikh rol u bioindykapii stanu navkolyshnoho seredovyshcha [Helix pomatia snails breeding at the territory of Ukrainian Polissiya. Ecological and functional, and faunistic aspects of snails' studying, their role in bioindication of the environment]. Zbirnyk naukovykh prats. Zhytomyr: Volyn, 15-17.

Hural-Sverlova. N. V., Hural R. I. (2012). Vyznachnyk nazemnykh moliuskiv Ukrainy [Identification of land snails of Ukraine]. Lviv, 216.

Donchenko, L.V. (2001). Bezopasnost pyshchevoi produktsyy [Food safety]. Moscwa: Pyshchepromyzdat, 528.

Zabarna, I. V., Bohatko, N. M., Yatsenko, I. V. (2009). Sposib vyznachennia stupenia svizhosti m'iasa ravlykiv bakterioskopichnym metodom. Zaiavka na Patent Ukrainy na korysnu model № u 201900992 vid 31.01.2019 r.

Leonov, S. V. (2005). Poshyrennia, struktura populiatsii i biolohiia rozmnozhennia krymskykh moliuskiv rodu Helix (Gastropoda, Pulmonata) [Spread, population structure and reproduction biology of Crimean snails of Helix genus (Gastropoda, Pulmonata)]. NAN Ukrainy. In-t zoolohii im. I. I. Shmalhauzena. Kyiv, 20.

Popov, V. N. (1996). Vinogradnyyye ulitki Kryma. [Grape snails of Crimea]. Priroda. Simfepropol', 1: 6-8. 
Reglament ES № 852/2004 Evropeyskogo parlamenta i soveta ot 29 aprelya 2004 goda po gigiyene pishchevykh produktov (OJ L 139, 30.4.2004, 1).

Reglament (ES) № 853/2004 Evropeyskogo Parlamenta i Soveta ob ustanovlenii spetsial'nykh gigiyenicheskikh pravil, podlezhashchikh primeneniyu $\mathrm{k}$ prodovol'stvennym tovaram zhivotnogo proiskhozhdeniya** (Strasburg, 29 aprelya 2004 goda). Redaktsiya vid 17.10.2008.

Rekomendovanyi Mizhnarodnyi kodeks hihiienichnoi praktyky stosovno svizhoho m'iasa. CAC/RCP 11-1976, Rev. 1 (1993).

Shevchuk, V. F., Burlaka, V. A., Kryvyi, M. M., Mamchenko, V.Yu. (2017). Bezpeka ta sanitarna yakist m'iasa slymakiv pry yikh utrymanni v umovakh promyslovoi fermy [Safety and sanitary quality of snails' meat during their breeding in industrial farms.]. Zbirnyk naukovykh prats aktualnykh problem ekonomichnykh nauk. Lviv. URL: http://archive.nbuv.gov.ua
Yakubchak, O. M., Halaburda, M. A. (2018). Analiz mikrobiolohichnykh nebezpechnykh faktoriv u kharchovomu lantsiuzi. [Analysis of microbiological hazards in the food chain.]. Navchalni posibnyky dlia VNZ. Kyiv: TOV «Vydavnytstvo» Yuston», 148.

Daguzan, J. (1989). Snail rearing or Helix aspersa Muller Sligs and Snail in World Agriculyure. British Grop Protection Council, Monograph., 41: 3-10.

Codex Alimentarius, (1993). Guidelines for the application of the Hazard Analysis Critical Control Point (HACCP) system. ALINORM 93/1 3A Appendix II Draft adopter by the 22nd Session of the Commission.

lakubchak, O. N., Zabarna, I. V., Taran, T. V. (2017). Effect of Farmazin ${ }^{\circledR}$ and Tilocyclinvet $^{\circledR}$ on microbiological, chemical, and microscopic characteristics of slaughtering products of broiler chickens. Ukrainian Journal of Ecology, 7(4): 125-133. doi: 10.15421/2017_95

\section{ЗабарНа І.В. (2019). БАКТЕРІОСКОПІЧНИЙ МЕТОД ВИЗНАЧЕННЯ СТУПЕНЯ}

СВІЖОСТІ М'ЯСА РАВЛИКІВ. Ukrainian Journal of Veterinary Sciences, 9(3): 21-27, https://doi.org/10.31548/ujvs2019.03.003.

Анотація. Метою роботи було удосконалити та визначити ступінь свіності м'яса равликів роду Неlіх за різної технологічної обробки бактеріоскопічним методом. Оскільки в сучасній науковій літературівідсутніданіщодовизначенняпоказників безпечностітаякостім'яса равликів, зокрема свіності м'яса різних видів та за різної технологічної обробки бактеріоскопічним методом, тому досліджуване питання є актуальним. Для дослідження використовували м'ясо равликів роду Неlix, видів: Helix pomatia, Helix aspersa maxima ma Helix aspersa muller. Було відібрано по 30 проб м'яса равликів кожного виду, вирощених на равликовій фермі Київської області.

Дослідження проводились в зимовий період, коли равлики знаходились в стані анабіозу. М'ясо равликів досліджували за різної технологічної обробки: живі, охолоджені і вареноморожені. За результатами дослідження встановлено, що м'ясо живих равликів було свіжим включно по 2 добу; сумнівної свіжості - з 3 доби включно по 5 добу; несвіжі - на 7 добу; свіне охолоджене м'ясо равликів було - включно по 2 добу; сумнівної свіжості - з 3 доби по 6 добу включно; несвіже - на 7 та 8 добу та свіже варено-морожене м'ясо равликів було в період зберігання упродовж 6 місяців за температури мінус $18{ }^{\circ} \mathrm{C}$. Ці дані є стабільними та достовірними, отже, чі показники можна використовувати при оцінюванні безпечності м'яса равликів за різної технологічної обробки і за різних термінів зберігання.

Ключові слова: мікроорганізми, Helix pomatia, Helix aspersa maxima, Helix aspersa muller, м'ясо равликів, бактеріоскопічні показники 